\title{
PRECEDENTES JUDICIAIS: UM OLHAR ESPECÍFICO EM FACE DA ATUAÇÃO DA PROCURADORIA-GERAL FEDERAL E O DIREITO DA PERSONALIDADE À APOSENTAÇÃO
}

\author{
Joelson Junior Bollotti* \\ Rodrigo Valente Giublin Teixeira**
}

Resumo: O presente estudo analisa o sistema de precedentes no Brasil como um sistema misto. Demonstra em que medida os precedentes previstos no art. 927 do CPC de 2015 vinculam juízes, tribunais e Administração Pública, considerando notadamente o regime jurídico constitucional estruturante. Com enfoque na Procuradoria-Geral Federal, elenca quais são os requisitos necessários para a correta aplicação do art. 927 do CPC, notadamente frente ao direito da personalidade à aposentação. Para tanto, por meio do método monográfico, defende o efetivo procedimento de "distinguishing". Conclui que apenas súmulas vinculantes e decisões em controle concentrado de constitucionalidade vinculam a Administração Pública.

Palavras-chave: Direito da personalidade à aposentação. Sistema brasileiro misto de precedentes. Efeito vinculante. Administração Pública. Procuradoria-Geral Federal.

\section{JUDICIAL PRECEDENTS: A SPECIFIC EYE ON THE FEDERAL ATTORNEY GENERAL'S PERFORMANCE AND THE RIGHT OF PERSONALITY TO RETIREMENT}

\begin{abstract}
The present study analyzes the precedent system in Brazil as a mixed system. Demonstrates to what extent the precedents provided for in art. 927 of the 2015 CPC are binding on judges, courts and public administration, notably considering the structuring constitutional legal regime. Focusing on the Federal Attorney General's Office, it lists what are the necessary requirements for the correct application of art. 927 of the CPC, notably against the personality's right to retirement. Through the monographic method, it defends effective "distinguishing". It concludes that only binding overviews and decisions on concentrated control of constitutionality bind Public Administration.
\end{abstract}

Key-words: Personality's right to retirement. Mixed Brazilian system of precedents. Binding effect. Public administration. Federal Attorney General.

\footnotetext{
* Joelson Júnior Bollotti. Procurador Federal. Mestrando no Programa de Pós-Graduação Stricto Sensu em Ciências Jurídicas pela Unicesumar - Centro Universitário de Maringá, Maringá (PR), Brasil. Endereço de postagem: Rua Platão, 1.754, centro, Alto Paraná-PR, CEP 87.750-000. Endereço eletrônico: bollotti@hotmail.com. CV: http://lattes.cnpq.br/7418086109176000.

** Rodrigo Valente Giublin Teixeira. Doutor pela PUC/SP. Bolsista Produtividade em Pesquisa do ICETI Instituto Cesumar de Ciência, Tecnologia e Inovação. Docente Titular do Programa de Pós-Graduação Stricto Sensu em Ciências Jurídicas e da Graduação na Unicesumar, Maringá (PR), Brasil. Advogado. Endereço de postagem: Avenida Guedner, 1.610, Zona 08, Maringá-PR, CEP 87.050-390, Endereço eletrônico: rodrigo@rodrigovalente.com.br. CV: http://lattes.cnpq.br/9514467370087290.
} 


\section{INTRODUÇÃO}

A aproximação em todo o mundo entre o direito romano-germânico, denominado de civil law, e o common law evidencia ainda mais o direito brasileiro como um sistema híbrido entre estes dois sistemas, ampliando-se a valorização dos precedentes judiciais.

Com a edição da Emenda Constitucional no 45 de 2004 e aprovação da súmula vinculante do Supremo Tribunal Federal (STF) em relação aos demais órgãos do Poder Judiciário e à administração pública direta e indireta, chega-se ao ápice da valorização da jurisprudência assentada, o que pode ressignificar o conceito que hoje temos do Princípio da Legalidade. Esta valorização, contudo, não significa que o Brasil tenha se tornado um país de tradição common law.

A problemática incide justamente em saber qual o correto alcance da palavra “observarão" empregada pelo art. 927, "caput”, do Código de Processo Civil (CPC), quando determina a observância dos precedentes por juízes e tribunais, e qual o alcance vinculativo em relação à Administração Pública.

Para tanto, será empregado o método hipotético-dedutivo, com análise das normas ("lato sensu") e doutrina relativa à temática.

O estudo será dividido em 4 capítulos. No primeiro capítulo trará considerações sobre as origens do civil law e do common law, demonstrando-se as peculiaridades e características de cada um.

No segundo capítulo, ficará demonstrado que o atual sistema brasileiro é um sistema híbrido entre o direito romano-germânico civil law e o common law, já que a própria Constituição Federal possibilita a construção de jurisprudência com grau variado de vinculação e também a construção do direito com base nas leis.

Em seguida, no terceiro capítulo, será discutida a correta aplicação do art. 927 do CPC quanto a precedentes vinculantes, demonstrando a necessidade de um efetivo procedimento de distinguishing, intimamente ligado à regra de proporcionalidade, pelos juízes e tribunais.

Por fim, no quarto capítulo, será demonstrada a peculiar posição da Advocacia-Geral da União (AGU), mais especificamente da Procuradoria-Geral Federal (PGF), frente à existência de um precedente judicial. Verificar-se-á quais precedentes têm verdadeira eficácia vinculativa em relação à Administração Pública e, ainda, qual o procedimento a ser adotado pelos membros da PGF frente à existência de um precedente elencado no art. 927 do CPC. 
Será, ainda, analisado o entendimento da PGF quando à aplicação do REsp nº 1.352.721/SP (Tema Repetitivo $n^{\circ}$ 629), considerando o direito à aposentação, que está intimamente ligado ao direito a alimentos, à vida, à dignidade da pessoa humana e, por conseguinte, aos direitos da personalidade.

O presente trabalho destina-se, portanto, a estabelecer parâmetros norteadores à correta aplicação dos precedentes previsto no CPC em nosso sistema misto, notadamente em face da atuação da Administração Pública Federal.

\section{BREVES CONSIDERAÇÕES SOBRE AS ORIGENS DO CIVIL LAW E DO COMMON LAW}

Inicialmente, é importante frisar que existem vários sistemas jurídicos diferentes pelo mundo. A origem de cada um deles está intimamente ligada à maneira como cada povo, em determinado espaço e tempo, entende o que é o direito.

O sistema jurídico da civil law é também conhecido como sistema romanogermânico. Neste sistema prevalece o texto escrito, onde vigora a lei.

A tradição romano-germânica tem suas origens nos séculos XII e XIII, no Renascimento da Europa Ocidental, período em que houve uma nova organização das cidades e do comércio. Época em que se entendeu que somente o direito poderia assegurar a ordem e a segurança jurídica necessárias ao progresso. Tornou-se imperioso, então, a separação entre o direito e a religião (DAVID, 2002, p. 39).

O direito romano-germânico tem como grande característica a compilação e codificação do direito. Essa característica contribuiu, sobremaneira, para cristalizar, em textos harmônicos, normas até então costumeiras, normas escritas esparsas, decisões jurisprudenciais consolidadas e a doutrina. Também não ficaram de fora dos textos consolidados as obras dos glosadores.

Houve uma preocupação com uma ordem de conceitos. O direito se revelou um sistema coeso de um conjunto de preceitos e normas que deveriam estar intimamente agrupados, tal qual um organismo vivo. O direito passou a ter precedência aos fatos, mesmo que os fatos não correspondessem ao direito (SOARES, 1999, p. 27).

Importava mais a racionalidade e logicidade do sistema do que os efeitos reais da aplicação da norma jurídica na vida em sociedade. Talvez por isso o método exegético 
empregado foi o silogismo, estruturado formalmente a partir de duas preposições (premissa maior e menor), das quais se obtêm por inferência uma terceira, a conclusão.

A cultura romanística passou a ocupar a posição de protagonista a partir da recomposição do Digesto pelos estudos da Universidade de Bolonha. A influência romana pela Europa Continental foi notória, o que contribuiu para que o civil law fosse o sistema vigente na maioria dos países ${ }^{1}$.

Noutro vértice, o common law iniciou-se com a invasão da Ilha Britânica pelos normandos, liderados pelo Rei Guilherme, o Conquistador (algumas vezes chamado de Guilherme, o Bastardo), no ano de 1.060, e se consolidou com a criação dos Tribunais do Rei (“Kings Courts" ou Tribunais de Westminster), no reinado de Eduardo I (1.272 a 1.307).

O Tribunal de Westminster se dividia em três grandes tribunais, a saber, o Tribunal do Tesouro do Rei, o Tribunal do Banco do Rei e o Tribunal das Causas Comuns.

Estes tribunais passaram a buscar o que era comum em matéria de direito aplicável a cada matéria, a fim de se alcançar uma espécie de unificação do direito. Daí vem a expressão do common law, ou seja, a busca da lei comum entre as diversas regiões, ocorrendo, a partir desse ponto uma formulação de uma série de precedentes, contudo, esses tribunais passaram a atuar como verdadeiros tribunais de exceção.

A distribuição da justiça era considerada como uma prerrogativa real, que os reis outorgavam a funcionários, os judges, que perambulavam pelo reino nas suas tarefas de representar o rei, ouvindo as queixas e emitindo um writ, ou seja, uma ordem dada pelo rei às autoridades, a fim de respeitarem, em relação ao beneficiado que obtinha o remédio, sua situação jurídica que seria definida por esse julgamento que, uma vez concedido, um jury composto de leigos julgaria as pretensões da pessoa beneficiada.

\footnotetext{
${ }^{1}$ Segundo ensinamento de Guido Fernando da Silva Soares (1999, p. 29-30) "o pensador que melhor caracteriza o sistema romano-germânico é Hans Kelsen, com sua Teoria Pura do Direito: o direito é uma construção escalonada (Stufenbau), tão racional e geométrica que, por isso mesmo, tem a forma de uma pirâmide, no ápice da qual se encontra uma norma fundamental (Grundnorm), a partir da qual as normas menos gerais retiram sua eficácia e vão perdendo sua generalidade, até aquelas normas colocadas na base (os contratos e as sentenças) que em princípio geral guarda sua eficácia, após percorrer outros campos de particularismo crescente (a constituição, a lei ordinária, o artigo...)". Acrescenta que "Os perigos em tal tipo de sistema se referem ao culto desmensurado à lógica formal e à racionalidade da construção dedutiva, tida como válida por seu próprio rigor arquitetural, por ela mesma válida, porque racional e coerente dentro do raciocínio abstrato, mas com um acentuado desprezo pelos resultados, na vida corrente.”. Finaliza esclarecendo que o casuísmo (doença da casuística) é o grande mal que o sistema romano-germânico teme, de tal forma, que mesmo a higidez do estudo de casos é, de certa forma, evitado ou, pelo menos, olhado com suspeição de vir a causar caos no edifício geométrico e piramidal.”
} 
Ou seja, para que a causa de um particular chegasse a ser apreciada pelos tribunais era preciso que fosse expedido um writ, uma espécie de petição inicial em que se dizia o que seria julgado e o que era pedido. Isso criou uma espécie de padronização.

Veja que a evolução era no sentido de elaborar as regras quanto às possibilidades de obterem-se as ações processuais. Obtidas estas, quanto ao julgamento sobre o direito contestado, não havia a menor previsão ou a menor preocupação.

A partir daí foi promulgado o Estatuto de Westminster II, por meio do qual o rei autorizava o chanceler a emitir do writ apenas em in consimili casu, isto é, em casos semelhantes já enquadrados em precedentes anteriores, entretanto, criou-se um problema em casos novos, em que as demandas não poderiam ser apreciadas.

Como explica Guido Fernando da Silva Soares (1999, p. 34) é bem evidente que tal sistema, formalístico e rígido, logo deveria sofrer radicais modificações, em razão das patentes injustiças; os recursos ao Rei, fora das regras processuais da common law, aos poucos, se tornam possíveis, sendo que o Rei os decidia, em matéria de consciência, e não mais por motivos estritamente jurídicos.

Um eclesiástico, o confessor do Rei, o Chanceler (Counsellor), cognominado the keeper of the king's conscience, passariam a conceder certas medidas, que aos poucos foram estendendo não mais em matéria de recursos das decisões, mas em matéria de conhecimento originário das causas.

A verdade é que o procedimento acima narrado se tornou tão frequente quando não houvesse um writ da common law que se verificou uma verdadeira justiça paralela às Courts of Westminster, com linguagem e precedentes próprios. Por isso, a partir do séc. XV, com os Tribunais da Chancelaria, passou-se a admitir um sistema paralelo, a Equity, visando corrigir imperfeições do common law, priorizando as circunstâncias do caso.

Com o Judicante Act de 1873, os dois sistemas se fundiram, para admitir um direito menos legislado e mais jurisprudencial: o stare decisis et no quieta movere (mantenha-se a decisão e não se moleste o que foi decidido), entendido como precedente de respeito obrigatório, correspondente à norma criada por uma decisão judicial e que, em razão do status do órgão que a criou, deve ser obrigatoriamente respeitada pelos órgãos de grau inferior.

No mapa abaixo (UOTTAWA, 2009) é possível verificar os sistemas comparados do direito pelo mundo e verificar que o isolamento das ilhas britânicas contribuiu para que o 
direito inglês não tivesse uma influência tão grande do direito romano, ou mesmo que influenciasse com maior força outros sistemas, como o brasileiro.

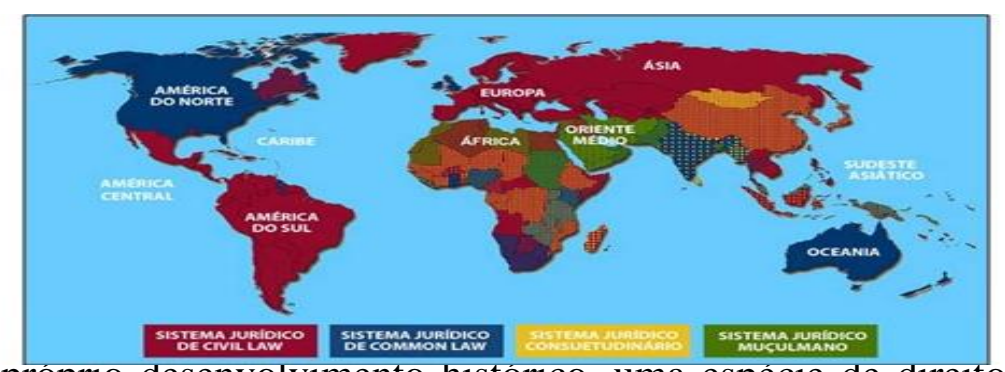

peculiar de seu proprio desenvolvimento histórıco, uma espécie de direito consuetudinario. Sua criação se deu sem as rupturas do direito romano e do posterior direito codificador de Napoleão Bonaparte.

Por fim, ressalte-se que embora o common law tenha origem no direito inglês, não se confunde com o sistema inglês propriamente dito, nem com o britânico ${ }^{2}$, nem com o anglosaxão, porque esse adjetivo designa o sistema dos direitos que regiam as tribos, antes da conquista normanda da Inglaterra (SOARES, 1999, p. 29-30).

\section{O ATUAL SISTEMA BRASILEIRO COMO UM SISTEMA HÍBRIDO}

O direito brasileiro é um sistema híbrido entre o direito romano-germânico - civil law e o common law - isto porque a Constituição Federal possibilita a formalização do judgemade law, ou seja, da jurisprudência, permitindo também a construção do direito com base no code-based legal systems, traduzindo: nas leis (SOARES; COUTO; COSTA, 2018, p. 567).

O Brasil, aliás, nunca foi refratário ao direito pretoriano, basta ver que a Constituição de 1891 já previa que a Justiça Federal, quando aplicasse leis estaduais deveria consultar "a jurisprudência dos tribunais locais e, vice-versa, as Justiças dos Estados consultariam a jurisprudência dos Tribunais Federais quando houvesse de interpretar leis da União" (BRASIL, 1981). Não se pode negar, todavia, que em nosso sistema a norma se releva como um paradigma evidentemente preponderante.

A CF/88 ao tratar da reserva legal e da isonomia da lei e perante a lei, determina que todos são iguais perante esta; que homens e mulheres são iguais em direitos e obrigações, nos termos da Constituição; e que ninguém será obrigado a fazer ou deixar de fazer alguma coisa

\footnotetext{
${ }^{2} \mathrm{O}$ adjetivo "britânico" é relativo à Grã-Bretanha, entidade política que inclui a Escócia, que pertence ao sistema da família romano-germânica.
} 
senão em virtude da lei, na forma do seu art. 50, “caput” e inc. I e II. Indica, ao assim dispor, que a principal fonte de revelação do Direito segue sendo a norma legal.

Isso não significa que tão somente a lei tenha força normativa no ordenamento pátrio. Pelo contrário, parece que cada vez mais as decisões dos tribunais superiores estão sendo colocadas em evidência, exercendo também evidentes efeitos normativos.

Cândido Rangel Dinamarco (2000, p. 1131-1132) chama a atenção para uma caminhada de valorização da jurisprudência, iniciada em 1963 com a súmula do STF, "uma das técnicas idealizadas com o objetivo de buscar saídas para o notório, antigo e angustiante problema da sobrecarga da Corte Suprema brasileira".

Aliás, com a promulgação da CF/88 essa caminhada de valorização da jurisprudência não foi interrompida. Longe disso, percebeu-se que foi sobremaneira intensificada.

Verificou-se a edição de leis que autorizavam órgão judiciais ou a Administração Pública a adotar providências de simplificação do procedimento judicial e a consequente abreviação da duração do processo.

Rodolfo de Camargo Mancuso (2019, p. 100-101), considera-se os seguintes exemplos (i) as regras que autorizam o relator a decidir monocraticamente recursos que têm como fundamento súmula ou jurisprudência predominante do respectivo tribunal, do STF ou de Tribunais Superiores ${ }^{3}$; (ii) as normas que dispensam o órgão fracionário do tribunal de remeter a questão de constitucionalidade para o seu plenário ou órgão especial, nos termos do art. 97 da CF/1988, quando já há anterior pronunciamento destes ou do Plenário do $\mathrm{STF}^{4}$; (iii) as normas que autorizam o órgão $a$ quo a não receber apelação que esteja em desconformidade com súmula do $\mathrm{STJ}$ ou do $\mathrm{STF}^{5}$ (iv) as normas que autorizam o órgão "a quo" a não conhecer do recurso extraordinário por falta de repercussão geral quando já houver um prévio pronunciamento do STF nesse sentido, em outro recurso tratando da questão constitucional idêntica ${ }^{6}$; (v) as normas que autorizam o órgão a quo a retratar-se em recuso extraordinário ou especial, ou julgá-los prejudicados, quando a mesma questão constitucional ou infraconstitucional ali versada já houver sido decidida no mérito pelo STF ou STJ

\footnotetext{
${ }^{3}$ Art. 38 da Lei 8.038/1990; art. 557 do CPC/73, na redação que lhe deram as Leis 9.139/1995 e 9.756/1998; art. $544, \S 4^{\circ}$, do CPC/73, na redação que lhe deram as Leis 8.950/1994 e 12.322/2010.

${ }^{4}$ Art. 481, parágrafo único, do CPC/73, na redação que lhe deu a Lei 9.756/1998.

${ }^{5}$ Art. $518,1^{\mathrm{a}}$, do CPC/1973, remunerado pela Lei $11.276 / 2006$.

${ }^{6}$ Arts. 543-A, $\S 5^{\circ}$, e 543-B, $\$ 2^{\circ}$, do CPC/73, acrescidos pela Lei 11.418/2006.
} 
(decisão-quadro), em recurso-amostra ${ }^{7}$; (vi) as normas que autorizam o Advogado-Geral da União a dispensar a propositura de ações e recursos quando a pretensão for contrária a decisões reiteradas do STF ou dos Tribunais Superiores" ou à "declaração de inconstitucionalidade proferida pelo STF, súmula ou jurisprudência consolidada do STF ou dos Tribunais Superiores"9.

Veja que todas as regras acima citadas têm apenas um "grau autorizativo", não impositivo, ou seja, sem efeitos vinculantes em relação aos respectivos Poderes.

Este cenário muda sobremaneira desde a edição da Emenda Constitucional no 45 de 2004, que inseriu o art. 103-A na CF, aprovando a súmula vinculante do STF, que têm efeito vinculante em relação aos demais órgãos do Poder Judiciário e à administração pública direita e indireta, nas esferas federal, estadual e municipal. Chega-se, então, ao ápice ou à expressão otimizada da tendencial valorização da jurisprudência assentada.

A eficácia expansiva da súmula vinculante do STF, em face de outros órgãos judiciais e mesmo da Administração Pública, pode ressignificar o conceito que hoje temos do Princípio da Legalidade. Segundo ensinamento de Gustavo Terra Elias (2012, p. 192), é como "se a cláusula da reserva da lei, prevista no inc. II do art. $5^{\circ}$ da Constituição da República ganhasse nova leitura, ou seja, ninguém será obrigado a fazer ou deixar de fazer alguma coisa senão em virtude de lei e enunciado de súmula vinculante.”.

Essa valorização dos precedentes judiciais no sistema jurídico brasileiro não significa, contudo, que o Brasil tenha se tornado um país de tradição common law. É preciso entender, conforme palavras de José Rogério Cruz e Tucci (2004, p. 304) que “o precedente é uma realidade em sistemas jurídicos histórica e estruturalmente heterogêneos, e que apresenta características próprias em diferentes legislações".

Michele Taruffo (2007, p. 710) indica essa rota de aproximação entre a common law e a civil law considerando que:

Pesquisas desenvolvidas em vários sistemas jurídicos têm demonstrado que a
referência ao precedente não é há tempos uma característica peculiar dos
ordenamentos do common law, estando agora presente em quase todos os sistemas,
mesmo os de civil law. Por isso, a distinção tradicional segundo a qual os primeiros
seriam fundados sobre os precedentes, enquanto os segundos seriam fundados sobre
a lei escrita, não tem mais - admitindo-se que realmente tenha tido no passado -
qualquer valor descritivo. De um lado, na verdade, nos sistemas de civil law se faz

\footnotetext{
${ }^{7}$ Arts. 543-B, $\$ 3^{\circ}$, e 543-C, $\$ 7^{\circ}$, ambos do CPC/73, acrescido pelas Leis 11.418/2006 e 11.672/2008, respectivamente.

${ }^{8}$ Art. $4^{\circ}$ da Lei $9.69 / 1997$.

${ }^{9}$ Art. 131 da Lei 8.213/1991.
} 
amplo uso da referência à jurisprudência, enquanto nos sistemas de common law se faz amplo uso da lei escrita e inteiras áreas desses ordenamentos - do direito comercial ao direito processual - são, na realidade, "codificadas"... 10

Verifica-se que o mesmo fenômeno vem ocorrendo no ordenamento jurídico brasileiro ao aproximar-se da tradição precedencialista, o que não significa uma identidade de sistemas ou tampouco uma perfeita identificação entre os regimes common law e a civil law.

É o que preleciona Dierlei José Coelho Nunes (2006, p. 526-527) ao esclarecer que o sistema brasileiro de súmulas não pode ser comparado com o sistema anglo-americano de cases, pois no sistema da "common law" se procura uma identificação discursiva de aspecto entre a causa em exame e o precedente, inclusive nos aspectos fáticos, em abordagem exaustiva. Por sua vez, no sistema de súmulas, com verbetes curtos e objetivos, a aplicação se dá de forma mais mecânica por parte do julgador, sem levar em consideração todo o suporte de discussão, mesmo jurídico, que conduziu o tribunal a tomar determinado posicionamento.

Devemos ter presente que o $\S 1^{\circ}$ do art. 489 do CPC considera não fundamentada - e, por conseguinte, nula (CF, art. 93, IX) - qualquer decisão judicial que "V - se limitar a invocar precedente ou enunciado de súmula, sem identificar seus fundamentos determinantes nem demonstrar que o caso sob julgamento se ajusta àqueles fundamentos." (BRASIL, 1988).

Certo é que não se pode refutar que no sistema brasileiro foi dado um notório espaço à eficácia precedencialista. Entre nós o meio pelo qual se revela a norma jurídica não é mais critério absoluto para a distinção entre os sistemas da common law e a civil law. Contudo, a norma legal segue sendo o elemento fundamente em nosso sistema.

É o que se infere, por exemplo, do art. $5^{\circ}$, da Lei 11.417/2006, que regulamenta o art. 103-A, da CF, e altera a Lei 9.784/1999, ao disciplinar a edição, a revisão e o cancelamento de enunciado de súmula vinculante pelo STF. No sobredito dispositivo legal está previsto que, sendo alterada ou revogada a lei subjacente a uma súmula vinculante, está última terá que ser modificada ou cancelada. Esta determinação indica uma prelação do direito escrito em face da interpretação dos tribunais sobre à questão posta em julgamento.

\footnotetext{
10 "Richerche svolte in vari sistemi giuridici hanno dimostrato che li riferimento al precedente no è più da tempo una caratteristica peculiare degli ordinamenti di common law, essendo ormai presente in quasi tutti i sistemi, anche di civil law. Quindi la distinzione tradizionale secondo la quale i primi sarebbero fondati sul precedente, mentre i secondi sarebbero fondati sulla legge scritta no ha più - ammesso che davvero l'abbia avuto in passato alcun valore descritivo. Da um lato, invero, nei sistemi di civil law si fa ampio uso del riferimento ala giurisprudenza, mentre nei sistemi di common law si fa ampio uso della legge scritta ed intere aree di questi ordinamenti - dal diritto commerciale al dirrito processuale - sono in realtà 'codificate'
} 
Podemos falar então, em um sistema híbrido. Há prevalência da lei. Não obstante isto, os precedentes judiciais - mesmo que não nos moldes do stare decisis et no quieta movere - têm valor irrefutável e devem, por força da própria lei, ser observados.

Certo é que no atual estado da arte há uma aproximação entre os regimes do common law e a civil law. Isso não significa dizer de forma simplista que há identidade entre eles.

No caso específico do sistema brasileiro de súmulas, veja que o $§ 1^{\circ}$ do art. 489 do CPC traz ao julgador, como imperativo, a obrigação de promover a integração da dimensão normativa contida no enunciado da súmula à dimensão fática analisada no precedente e, por conseguinte, analisar a sua identificação do precedente vinculante com o caso posto. Se a decisão não realiza o distinguishing - no sentido de resultado ou conclusão pela aplicação ou distinção entre caso posto e precedente - considera-se não fundamentada.

Cabe aqui, respeitosamente, uma crítica, pois na prática verifica-se que em muitos casos o magistrado não faz essa análise, isto é, o distinguishing exigido pela lei. A aplicação do enunciado da súmula se dá de forma pura e simples como se tratasse de um dispositivo legal que não demandasse maiores indagações.

Por tudo o que foi exposto até aqui, não se pode negar que o sistema brasileiro tem como norte principal a lei. Não obstante, cada dia mais são valorizados os precedentes, que vêm ocupando posição de destaque no ordenamento jurídico. Podemos então entender o sistema brasileiro como um sistema híbrido entre o common law e a civil law.

\section{A CORRETA LEITURA DO ART. 927 DO CPC QUANTO A PRECEDENTES VINCULANTES}

$\mathrm{O}$ art. 927 , caput, do CPC/15 prevê que os juízes e os tribunais observarão as decisões do STF em controle concentrado de constitucionalidade, os enunciados de súmulas vinculantes, os acórdãos em incidente de assunção de competência ou de resolução de demandas repetitivas e em julgamento de recursos extraordinário e especial repetitivos, os enunciados das súmulas do STF e do STJ, em suas respectivas competências, a orientação do plenário ou do órgão especial aos quais estiverem vinculados.

$\mathrm{O} \S 1^{\circ}$ do mesmo art. 927 do CPC determina que os juízes e os tribunais observarão o disposto no art. 10 e no art. $489, \S 1^{\circ}$, quando decidirem com fundamento no art. 927 . Ou seja, os juízes e os tribunais deverão oportunizar às partes o direito de se manifestarem sobre o fundamento sobre o qual irão decidir. Deverão, portanto, realizar um correto distinguishing, 
no sentido de resultado pela aplicação do precedente ou de distinção entre os casos, observando um contraditório qualificado, com enfrentamento de todos os argumentos deduzidos no processo e capazes de, em tese, infirmar a conclusão adotada pelos julgados, evitando o emprego de conceitos jurídicos indeterminados, sem explicar o motivo concreto de sua incidência no caso concreto.

O emprego pelo art. 927 do CPC da palavra "observarão" faz com que uma leitura açodada do dispositivo leve à conclusão de que o significado do termo dê eficácia vinculante, em toda e qualquer hipótese, aos precedentes e súmulas nele indicados. Essa conclusão, contudo, não é tecnicamente correta.

Parece-nos mais correto que no procedimento de distinguishing, além das cautelas acima especificadas, os juízes e tribunais levem em conta o princípio da proporcionalidade. Até mesmo porque o princípio da proporcionalidade parece estar intimamente ligado ao processo de distinguishing propriamente dito.

Segundo ensinamento de Virgínio Afonso da Silva (2002, p.15) a "regra da proporcionalidade" é uma regra de interpretação e aplicação do direito que tem por objetivo último fazer com que nenhuma restrição a direitos fundamentais tome dimensões desproporcionais. É, segundo ele, uma restrição às restrições.

Dito isso, deve-se ter em mente que o postulado da proporcionalidade estrutura-se em três elementos, também chamados, na lição de Hélio Ricardo Diniz Krebs (2015, p. 69), de exames, testes, sub-regras, ou regras de argumentação, pelos quais deve passar o ato impugnado, quais sejam: 1) a adequação; 2) a necessidade; 3) a proporcionalidade em sentido estrito, esta também denominada de técnica ou lei de ponderação.

Os significados dos três elementos são esclarecidos, de maneira magistral, por Humberto Ávila (2008, p. 28), que explica que uma medida é adequada quando o meio escolhido é apto para alcançar o resultado pretendido; necessária, se, dentre todas as disponíveis e igualmente eficazes para atingir um fim almejado, é a menos gravosa em relação aos direitos envolvidos; proporcional ou correspondente, se, relativamente ao fim perseguido, não restringir excessivamente os direitos envolvidos no caso posto em discussão.

Antes da vigência do CPC/15, Bonavides (2008, p. 82-93) defendia que a proporcionalidade não se encontrava prevista expressamente como uma norma geral de direito, mas sim como norma esparsa por todo a Constituição. Segundo ele, a positividade do princípio da proporcionalidade decorreria de outras normas afins ao art. $5^{\circ}, \S 2^{\circ}$, da CF. Este 
artigo é uma cláusula geral de abertura e preceitua que "Os direitos e garantias expressos nesta Constituição não excluem outros decorrentes do regime e dos princípios por ela adotados, ou dos tratados internacionais em que o Brasil seja parte" (BRASIL, 2015).

O CPC/15 prevê, no art. $8^{\circ}$, o princípio da proporcionalidade nos seguintes termos: “Ao aplicar o ordenamento jurídico, o juiz atenderá aos fins sociais e às exigências do bem comum, resguardando o promovendo a dignidade da pessoa humana e observando a proporcionalidade, a razoabilidade, a legalidade, a publicidade e a eficiência".

Ora, não nos parece que o legislador tenha previsto gratuitamente o princípio da proporcionalidade no $\mathrm{CPC}$ e, ao mesmo tempo, não tenha pensado em aplica-lo mesmo existindo precedentes judiciais vinculantes. Se assim quisesse o teria feito expressamente. Contudo, não houve vedação nesse sentido. Parece-nos, inclusive, que o próprio procedimento de distinguishing demanda uma análise atenta ao princípio da proporcionalidade.

Deve-se ter consciência, todavia, que por mais que o CPC preveja expressamente a aplicação da proporcionalidade, é incomum que se atribua ao parâmetro a dimensão apropriada. Por isso, é importante o emprego de esforços doutrinários para procurar o estreitamento entre a letra da lei e a realidade que se apresenta no dia-a-dia.

Um primeiro desdobramento a ser extraído da conclusão de que o princípio da proporcionalidade tem previsão expressa e deve ser aplicado mesmo existindo precedente vinculante é aquilo que se denominou de "proporcionalidade endoprocessual". É a observância de garantias processuais, como a observância do devido processo legal.

É socialmente desejável e importante que juízes e tribunais atuem no sentido de enriquecer o ordenamento jurídico. No Brasil, a necessidade de regras jurídicas mais específicas parece ser um dos fatores que ensejaram a aprovação de precedentes vinculantes.

$\mathrm{Na}$ atividade jurisdicional vigente no ordenamento jurídico brasileiro, os juízes e tribunais cumprem uma dupla tarefa. A primeira de se voltar para o passado, resolvendo uma disputa entre as partes interessadas. A segunda, a função de enriquecer o ordenamento jurídico, com um objetivo mais prospectivo, possibilitando que os integrantes da sociedade planejem seus atos futuros ${ }^{11}$.

\footnotetext{
${ }^{11}$ Nesse sentido, o professor William Pugliese (2016, p. 38) defende que "Essa preocupação temporal torna a atividade jurisdicional diferente daquela observada na civil law. Ao mesmo tempo, os cuidados a serem tomados pelo magistrado tornam-se maiores, pois ele deve solucionar uma questão particular e conciliar as tensões entre as normas jurídicas em vigor e os efeitos de sua decisão nos demais casos."
} 
É nesse sentido que juízes e tribunais, mesmo diante de um caso concreto em que exista um precedente, podem e devem fazer uso do princípio da proporcionalidade.

No caso, as regras de Thomas Rosa Bustamante (2006, p. 5) podem ser úteis. Este autor indica que a proporcionalidade pode se decompor nas seguintes regras de argumentação:

“1. Regra da adequação: Se M1 não é adequado para fomentar o fim F, exigido pelo princípio P1, então M1 não é exigido por P1 (M1 é indiferente para p1). Em tais situações, se M1 afeta de alguma maneira um outro princípio $\mathrm{P} 2$, M1 está proibido por P2;

2. Regra da necessidade: Se há dois meios (M1 e M2) para fomentar o fim F, exigido pelo princípio $\mathrm{P} 1$, sendo que cada um deles promove o fim na mesma medida, mas M1 interfere na realização do princípio $\mathrm{P} 2$ em maior medida que M2, então deve ser empregado o meio M2.

3. Regra da proporcionalidade em sentido estrito: Os motivos que fundamentam uma medida que restringe de alguma maneira um direito fundamental devem ter peso suficiente para preponderar sobre o direito fundamental afetado por ela, encontrando condições de justificar a sua restrição.”

Por fim, importante ressaltar que o próprio CPC previu os institutos do distinguishing como método de aplicação dos precedentes e, ainda, do distinguishing como método de superação dos precedentes judiciais. As previsões de tais institutos vão ao encontro da conclusão de que o princípio da proporcionalidade pode e deve ser aplicado em face da existência de precedentes vinculantes.

\section{POSIÇÃO DA ADVOCACIA-GERAL DA UNIÃO - AGU, MAIS ESPECIFICAMENTE DA PROCURADORIA-GERAL FEDERAL, FRENTE ̀̀ EXISTÊNCIA DE UM PRECEDENTE JUDICIAL}

Os precedentes têm uma característica importante de uniformização da jurisprudência, a teor dos artigos 926 e 927, ambos do CPC. O sistema de precedentes judiciais brasileiro adota como princípios uma jurisprudência estável, íntegra e coerente. Estes princípios têm como objetivo a segurança jurídica, já que assegura a previsibilidade dos seus resultados e, a medida do possível, a imutabilidade dos julgados. Por fim, vincula juízes e Tribunais nas decisões, nos termos acima expostos.

Os conceitos de uma jurisprudência estável, íntegra e coerente estão intimamente ligados ao princípio da segurança jurídica. Aos tribunais cabe o dever de uniformizá-la, evitando a propagação de teses jurídicas díspares acerca de situações fáticas semelhantes.

A exigência de coerência produz efeitos internos e externos. Externamente, os tribunais devem coerência às suas próprias decisões e à linha evolutiva do desenvolvimento da jurisprudência. Ou seja, não pode o tribunal contrariar o seu próprio entendimento, salvo a 
possiblidade de superação do entendimento overruling. Do ponto de vista interno, o dever de coerência relaciona-se à construção do precedente e, portanto, ao dever de fundamentação, evitando-se uma decisão suicida, ou seja, quando da fundamentação não decorra logicamente o provimento final (dispositivo).

O dever de integridade relaciona-se com a unidade do Direito, ligada à proposta de Ronald Dworkin (1999, p. 488) de noção de direito como integridade, impondo sobretudo ao tribunal que decida em conformidade com o Direito, observada toda a sua complexidade.

Percebe-se, portanto, a ausência de utilidade de se continuar a recorrer de decisões judiciais que aplicam corretamente, sob o ponto de vista infralegal e constitucional, determinado precedente judicial consolidado, pois a defesa judicial não deve ser interpretada como uma aventura jurídica em que o objetivo é levar o processo até as últimas instâncias. Com maior razão no que se refere ao ente público, em que seus membros devem ter como foco central a condução processual de forma a resguardar o erário e os interesses do Estado.

É nesse contexto que foi expedida a Portaria $n^{\circ}$ 488/2016 da AGU, que autoriza a PGF, nos termos de seu art. $3^{\circ}$, a expedir orientação aos Procuradores Federais para reconhecimento da procedência do pedido, abstenção de contestação e de recurso e desistência dos recursos já interpostos, nos casos nela previstos ${ }^{12}$.

\footnotetext{
${ }^{12}$ Art. $3^{\circ}$ A Procuradoria-Geral Federal poderá orientar os Procuradores Federais a reconhecer a procedência do pedido, a abster-se de contestar e de recorrer e a desistir dos recursos já interpostos, quando a pretensão deduzida ou a decisão judicial estiver de acordo com: I - acórdão transitado em julgado proferido pelo Superior Tribunal de Justiça em sede de recurso especial representativo de controvérsia, processado nos termos do artigo 1.036 do CPC; II - acórdão transitado em julgado, proferido pelo Superior Tribunal de Justiça em sede de recurso especial em incidente de resolução de demandas repetitivas, processado nos termos do artigo 987 do CPC; III - acórdão transitado em julgado, proferido pelo Superior Tribunal de Justiça em sede de incidente de assunção de competência, processado nos termos do artigo 947 do CPC; IV - acórdão transitado em julgado proferido pela Corte Especial e súmula do Superior Tribunal de Justiça, caso a controvérsia sobre matéria infraconstitucional seja atual; V - acórdão transitado em julgado, proferido pelo Tribunal Superior do Trabalho em sede de recurso de revista representativo de controvérsia, processado nos termos do art. 896-C da Consolidação das Leis do Trabalho (CLT); VI - acórdão transitado em julgado, proferido pelo Tribunal Superior do Trabalho em sede de recurso de revista em incidente de resolução de demandas repetitivas, processado nos termos do artigo987 do CPC, conforme o artigo $8^{\circ}$ da Instrução Normativa n³9/2016, aprovada pela Resolução $n^{\circ}$ 203, de 15 de março de 2016, do Pleno do TST; VII - acórdão transitado em julgado, proferido pelo Tribunal Superior do Trabalho em sede de incidente de assunção de competência, processado nos termos do artigo 947 do CPC, conforme o artigo $3^{\circ}, \mathrm{XXV}$, da Instrução Normativa ${ }^{\circ}$ 39/2016, aprovada pela Resolução $n^{\circ} 203$, de 15 de março de 2016, do Pleno do Tribunal Superior do Trabalho; VIII - acórdão transitado em julgado proferido pelo Pleno e súmula do Tribunal Superior do Trabalho, caso a controvérsia sobre matéria infraconstitucional seja atual; IX - acórdão transitado em julgado, proferido pela Turma Nacional de Uniformização dos Juizados Especiais Federais em sede de incidente representativo de controvérsia, processado nos termos do art. $7^{\circ}$, VII, a, do Regimento Interno da Turma Nacional de Uniformização, nos processos que tramitam nos Juizados Especiais Federais. Parágrafo único. Na elaboração da orientação de que trata o caput deste artigo, deverá ser considerada a probabilidade de reversão da respectiva tese pelo Superior Tribunal de Justiça ou pelo Supremo Tribunal Federal, devendo, nesta
} 
O ponto fulcral em todas as hipóteses permissivas elencadas no art. $3^{\mathrm{a}}$ da Portaria $\mathrm{n}^{\mathrm{o}}$ 488/2016 é saber se há probabilidade de reversão da tese desfavorável à Administração Pública, notadamente se é possível levar a questão à apreciação do STF, tratando-se de matéria que aventa ofensa direta à $\mathrm{CF}$.

Se o STF ou o STJ, cuidando-se de matéria exclusivamente infraconstitucional com ofensa apenas reflexa à Constituição, consolidou jurisprudência contrária à tese defendida pela Administração Pública acerca de determinado tema, o melhor a fazer é abster-se de contestar, recorrer ou desistir dos recursos já interpostos.

Urge gizar que mesmo após a autorização para não recorrer e desistir dos recursos já interpostos nas situações especificadas caso a caso pela Procuradoria Federal, mostra-se imprescindível o efetivo cotejo pelo Procurador Federal que atua no caso concreto com o paradigma delineado no acórdão, buscando-se verificar se há a subsunção específica da matéria ao aludido precedente, em verdadeiro procedimento de distinguishing lato sensu.

Havendo peculiaridades que distingam, fática ou juridicamente, a situação concreta do paradigma julgado, a apresentação da manifestação cabível não estará dispensada, mesmo perante Tribunal Superior.

Do mesmo modo, cumpre salientar que a existência de parecer referencial (ato normativo que deve ser expedido caso a caso) não exime o Procurador Federal de analisar os aspectos jurídicos não abarcados na orientação expedida pelo Departamento de Contencioso da PGF, a teor do que dispõe o artigo 13 da Portaria PGF $n^{\circ}$ 255/2017 ${ }^{13}$.

As hipóteses abarcadas pela Portaria n 488/2016 da AGU não afastam o dever de contestar, recorrer ou impugnar especificamente nos casos previstos em seu art. 12, como de ocorrência das defesas processuais previstas no art. 337 do CPC ou de outras questões incidentes processuais que possam implicar a extinção da ação; prescrição; decadência; controvérsia a respeito da matéria de fato; pagamento administrativo; acordo judicial ou extrajudicial entre as partes; verificação de circunstâncias específicas do caso concreto que possam modificar ou extinguir a pretensão da parte adversa; discordância nos casos que

última hipótese, ser ouvida a Secretaria-Geral de Contencioso, quando a matéria for comum à União e às autarquias e fundações públicas federais.

13 “Art. 13. A existência de Parecer Referencial não exime o procurador federal de analisar os aspectos jurídicos não abarcados na orientação expedida pelo DEPCONT/PGF.” ADVOCACIA-GERAL DA UNIÃO. Procuradoria-Geral Federal. Portaria $n^{\circ}$ 255/2017/PGF/AGU. Disponível em: https://agu.gov.br. Acesso em: 25 out. 2019. 
exigem atuação específica quanto a valores ou cálculos apresentados pela parte ou pelo juízo; situação fática distinta ou questão jurídica não examinada nos precedentes dos Tribunais Superiores e da Turma Nacional de Uniformização que imponha solução jurídica diversa; e superação dos precedentes judiciais, inclusive por alteração legislativa.

O exercício processual acima exposto foi aplicado pela PGF quanto os parâmetros para aplicação do Recurso Especial (REsp) n ${ }^{\circ}$ 1.352.721/SP, julgado sob o rito repetitivo, para garantir a concretude do direito fundamental à prestação previdenciária, que tem natureza jurídica de direito social, de índole alimentar. Portanto, é um direito humano que emana da própria dignidade da pessoa humana e têm íntima ligação aos direitos da personalidade.

Especificamente quanto ao REsp n $n^{\circ} 1.352 .721 / \mathrm{SP}$, deve-se chamar a atenção que se cuidava de recurso interposto pelo Instituto Nacional do Seguro Social (INSS), com fundamento na alínea "a" do inc. III do art. 105 da CF, contra acórdão proferido pelo Tribunal Regional Federal (TRF) da $3^{\text {a }}$ Região, sob a alegação de violação dos art. 267, inciso IV, 269, inc. I, 283, 333, inc. I, e 396, todos do CPC/73. No referido recurso, o INSS sustentou que a parte autora deixou de instruir seu pedido inicial com documentos que comprovassem o exercício de atividade rural, consoante exigência legal prevista no art. $55, \S 3^{\circ}$, da Lei n. 8.213/91, motivo pelo qual o feito deveria ser sido extinto com resolução do mérito.

Afetado como representativo de controvérsia segundo a sistemática do art. 1.036 do CPC, o REsp $n^{\circ}$ 1.352.721/SP (Tema Repetitivo $n^{\circ}$ 629) foi julgado pela Corte Especial do STJ, tendo o Relator, Ministro Napoleão Nunes Maia Filho. A Corte Especial do STJ, por conseguinte, ao julgar o REsp repetitivo $\mathrm{n}^{\circ}$ 1.352.721/SP, negou provimento ao recurso do INSS e fixou a tese de que a ausência de conteúdo probatório eficaz a instruir a inicial implica a carência de pressuposto de constituição e desenvolvimento válido do processo, impondo sua extinção sem o julgamento do mérito, com a consequente possibilidade de o autor intentar novamente a ação, caso reúna os elementos necessários à tal iniciativa.

Contra o mencionado acórdão, o INSS interpôs recurso extraordinário, o qual foi inadmitido pela Vice-Presidência do STJ, em razão da preclusão. Inconformado, o INSS apresentou agravo (ARE $n^{\circ} 1.015 .816 / \mathrm{SP}$ ), cujo seguimento foi denegado pelo Relator (Ministro Dias Toffoli) e, na sequência, agravo regimental, que teve o provimento negado pela Segunda Turma do STF, por entender haver ofensa apenas reflexa à CF. 
Registre-se que, ante a ausência de novos recursos, o acórdão proferido no REsp Repetitivo $\mathrm{n}^{\mathrm{o}}$ 1.352.721/SP transitou em julgado em 15.09.2017, sem probabilidade, pelo menos de imediato, de reversão da respectiva tese pelo STJ ou pelo STF, inexistindo julgados atuais em sentido contrário aos acima referidos, pois constatou a PGF que o caso em espeque se subsumia à hipótese prevista no art. $3^{\circ}$, inc. I e parágrafo único, da Portaria AGU $\mathrm{n}^{\circ}$ 488/2016, editando, por conseguinte, o Parecer Referencial nº 22/2017.

Concluiu a PGF, todavia, que a tese fixada pelo STJ se limita à insuficiência/falta de prova documental. Desse modo, entendeu que a carência de qualquer outro tipo probatório, como, por exemplo, de prova testemunhal ou prova pericial, não tem albergue na mencionada tese, ensejando a extinção do processo com resolução do mérito.

Vela frisar que a discussão objeto do REsp Repetitivo no 1.352.721/SP é meramente processual e somente estará amadurecida após a fase instrutória do processo. Deve-se, portanto, priorizar a necessidade de observância do princípio da primazia da resolução do mérito que tem previsão nos artigos $4^{\circ}$ e 139 , IX, do CPC.

Mesmo após a autorização da PGF para não recorrer ou desistir dos recursos já interpostos nas situações ora especificadas, mostra-se imprescindível o efetivo cotejo do caso concreto com o paradigma delineado no acórdão do REsp $\mathrm{n}^{\circ} 1.352 .721 / \mathrm{SP}$, buscando-se verificar se há a subsunção específica da matéria ao aludido precedente.

Vê-se, portanto, que as peculiaridades das demandas previdenciárias, mormente as dificuldades enfrentadas pelo segurado para comprovar documentalmente que preenche os requisitos necessários para a concessão do benefício, justificam a flexibilização dos rígidos institutos do processo civil, sobretudo para garantir a concretude do direito fundamental à prestação previdenciária a que faz "jus" o segurado, ligado à dignidade da pessoa humana, à vida e aos direitos da personalidade.

Verifica-se, pelo exposto, que a comezinha divisão feita pela doutrina entre precedentes vinculantes e persuasivos tem especial importância e significado quando tratamos de Administração Pública.

Em verdade, apenas as súmulas aprovadas por 2/3 dos ministros do STF, na forma do art. 103-A e $\$ 3^{\circ}$ da CF, e as decisões do STF em controle concentrado de constitucionalidade impõem à Administração Pública Federal verdadeira eficácia vinculante. Os demais casos devem ser tratados com as cautelas já especificadas, pois dirigidos especificamente à 
jurisdição, já que o caput do art. 927 do CPC determina que "Os juízes e os tribunais observarão" aos precedentes elencados nos incisos deste artigo. A determinação não é dirigida especificamente à Administração Pública (OLIVEIRA, 2019, p. 62).

Veja que tanto as súmulas vinculantes quanto as decisões em controle concentrado de constitucionalidade têm assento constitucional, conforme se extrai da redação dos arts. 102 , I; 103-A e $\$ 3^{\circ}$, da CF. Por observarem um contraditório qualificado, ou nas palavras de Alexandre Câmara (2015, p. 63), subjetivamente ampliado, têm atributos de efeitos vinculantes. Para a Administração Pública esse contraditório é imprescindível, tendo em vista que, na grande maioria dos casos, maneja em juízo interesses indisponíveis.

Acrescente-se a isso que a CF tem a legalidade como princípio estruturante da Administração Pública e como cláusula pétrea, vinculando sobremodo a atuação dos agentes administrativos. Portanto, “apenas poderia ser afastada mediante uma norma superior de competência, que é a norma constitucional”' (OLIVEIRA, 2019, p. 127).

\section{CONCLUSÃO}

Embora o sistema brasileiro tenha sua origem evidentemente ligada ao sistema civil law, o atual sistema vigente no Brasil pode ser considerando híbrido ou misto entre o romanogermânico - civil law e o common law, pois a Constituição Federal possibilita a formalização do judge-made law (jurisprudência), permitindo também a construção do direito com base no code-based legal systems, ou seja, nas leis.

No atual estágio da arte, há uma nítida aproximação entre os regimes de common law e civil law. Não há, contudo, uma simples identidade entre eles.

Neste contexto, se revela sobremaneira importante que juízes e tribunais realizem de forma correta o procedimento de distinguishing, no sentido de resultado pela aplicação do precedente ou de distinção entre os casos, observando um contraditório qualificado, com enfrentamento de todos os argumentos deduzidos no processo e capazes de, em tese, infirmar a conclusão adotada pelos julgados, evitando o emprego de conceitos jurídicos indeterminados, sem explicar o motivo de sua incidência no caso concreto. Deve-se ter em conta neste processo a "regra da proporcionalidade", que acaba intimamente ligada ao próprio procedimento de distinguishing.

Juízes e tribunais devem, portanto, ter especial atenção quando da aplicação dos 
precedentes elencados no art. 927 do CPC, pois não vinculam simplesmente por existirem no mundo jurídico.

No presente estudo procurou-se demonstrar a peculiar situação da Administração Pública em face da existência de precedentes judiciais. Demonstrou-se que o princípio da legalidade é princípio estruturante da Administração Pública e, como cláusula pétrea, vincula sobremodo a atuação dos agentes administrativos. Somente pode ser afastado mediante uma norma superior de competência, que é a norma constitucional.

Defendeu-se a ausência de utilidade de se continuar a recorrer de decisões judiciais que aplicam corretamente, sob o ponto de vista infralegal e constitucional, determinado precedente judicial consolidado, pois a defesa judicial não deve ser interpretada como uma inconsequente aventura jurídica em que o objetivo é levar o processo até as últimas instâncias.

Nessa perspectiva, analisou-se a Portaria nº 488/2016 da Advocacia-Geral da União, que autoriza a PGF, nos termos de seu art. $3^{\circ}$, a expedir orientação aos Procuradores Federais para reconhecimento da procedência do pedido, abstenção de contestação e de recurso e desistência dos recursos já interpostos, nos casos nela previstos.

Analisou-se, o entendimento da PGF quando à aplicação do REsp $n^{\circ} 1.352 .721 / \mathrm{SP}$ julgado pela Corte Especial do STJ, e verificou-se que, em matéria previdenciária, a ausência de conteúdo probatório eficaz a instruir a inicial implica a carência de pressuposto de constituição e desenvolvimento válido do processo, impondo sua extinção sem a resolução do mérito, com a consequente possibilidade de o autor intentar novamente a ação, caso reúna os elementos necessários à tal iniciativa, tendo em vista o tratamento especial que deve ser dado ao direito à aposentação, intimamente ligado ao direito a alimentos, à vida, à dignidade da pessoa humana e, por conseguinte, aos direitos da personalidade.

O ponto fulcral da temática consiste em ter bem claro que apenas as súmulas vinculantes e as ações diretas de inconstitucionalidade vinculam de fato a Administração Pública, pois são hipóteses previstas diretamente na Constituição Federal. Deve-se ter presente também que as hipóteses permissivas de reconhecimento da procedência do pedido, abstenção de contestação e de recurso e desistência dos recursos já interpostos previstas no art. $3^{\text {a }}$ da Portaria $n^{\circ}$ 488/2016 têm como núcleo fundante a não probabilidade de reversão da tese desfavorável à Administração Pública junto ao Supremo Tribunal Federal.

\section{REFERÊNCIAS}


ÁVILA, Humberto. A distinção entre princípios e regras e a redefinição do dever de proporcionalidade. Revista Diálogo Jurídico, ano I, vol. I, n. 4, p. 28, Salvador, jul. 2001 (versão on-line).

BONAVIDES, Paulo. A quinta geração de direitos fundamentais. Revista Brasileira de Direitos Fundamentais \& Justiça, v. 2, n. 3, p. 82-93, 2008.

BRASIL. Constituição da República Federativa do Brasil de 1988. 2020.

BUSTAMANTE, Thomas da Rosa de. Princípios, regras e a fórmula de ponderação de Alexy: um modelo para argumentação jurídica? Revista de Direito Constitucional e Internacional. Vol. 54, São Paulo: RT, jan. 2006 (versão on-line).

CÂMARA, Alexandre Freitas. O novo processo civil brasileiro. São Paulo: Atlas, 2015.

CINTRA, Antonio Carlos de Araujo; GRINOVER, Ada Pellegrini; e DINAMARCO, Cândido Rangel. Teoria geral do processo. 25 ed. São Paulo: Malheiros Editores, 2009.

CRUZ E TUCCI, José Rogério. Precedentes judiciais como fonte do direito. São Paulo: Revista dos Tribunais, 2004.

DINAMARCO, Cândido Rangel. Fundamentos do processo civil. 6.ed. São Paulo: Malheiros, 2006. t. I e II.

DWORKIN, Ronald. O império do Direito. São Paulo: Martins Fontes, 1999, p. 488.

ELIAS, Gustavo, Terra. Súmula vinculante n. 3 do Supremo Tribunal Federal: um estudo do conflito entre as mutações do direito e a busca de segurança jurídica no controle dos atos de aposentadoria pelos Tribunais de Contas. Revista Interesse Jurídico. n. 73. Rio Grande do Sul, 2012.

KREBS, Hélio Ricardo Diniz et al. A importância dos direitos fundamentais para o sistema de precedentes. 2015.

LARENZ, Karl. Metodologia da ciência do direito. 5. ed. Lisboa: Calouste Gulbenkian, 2009, p. 611.

MANCUSO, Rodolfo de Camargo. Sistema brasileiro de precedentes: natureza, eficácia, operacionalidade. Editora JusPODIVM, 2019.

NERY JR, Nelson; WAMBIER, Teresa Arruda Alvim. Aspectos polêmicos e atuais dos recursos cíveis: e assuntos afins. V. 12. São Paulo: Editora Revista dos Tribunais, 2006.

NUNES, Dierle José Coelho. Comentários acerca da súmula impeditiva de recurso (Lei 11.276/2006) e do julgamento liminar de ações repetitivas (Lei 11.277/2006). Do duplo grau de jurisdição e do direito constitucional ao recurso (contraditório sucessivo) - 
Aspectos normativos e pragmáticos. Revista de Processo. vol. 137. São Paulo: Revista dos Tribunais, 2006.

OLIVEIRA, Weber Luiz de et al. Precedentes judiciais na administração pública: limites e possibilidades de aplicação. 2019.

PUGLIESE, William. Precedentes e a civil law brasileira: interpretação e aplicação do novo Código de processo civil. Thomson Reuters Revista dos Tribunais, 2016, p. 38.

SANTOS, Júlio César. O precedente à brasileira: súmula vinculante e o incidente de resolução de demandas repetitivas. In: Revista de Processo. vol. 208, ano 37, p. 203-240, São Paulo: Editora Revista dos Tribunais, jun. 2012.

SILVA, Virgílio Afonso da. O proporcional e o razoável. São Paulo: RT 798/15, abr. 2002 (versão on-line).

SOARES, Guido Fernando Silva. Common law: introdução ao direito dos EUA. Editora Revista dos Tribunais, p. 32-33, 1999.

SOARES, Marcelo Negri; COUTO, Monica Bonetti; COSTA, Jessica Chaves. Dever de fundamentação e precedentes no novo cpc: uma análise à luz do modelo constitucional de processo. Revista Eletrônica do Curso de Direito da UFSM, v. 13, n. 2, p. 554-576, 2018.

TARUFFO, Michele. Precedente e giurisprudenza. Rivista Trimestrale di Diritto e Procedura Civile. n. 3. Milão. set. 2007.

UOTTAWA. Droit Civil. Sistemas Comparados de Direito no Mundo. JuriGlobe. 2009. Disponível em htpp://www.droitcivil.uottawa.ca/word-legal-systems/eng-monde-large.html. Acesso em 28/03/2020. 